GEOLOGICAL SURVEY CIRCULAR 802

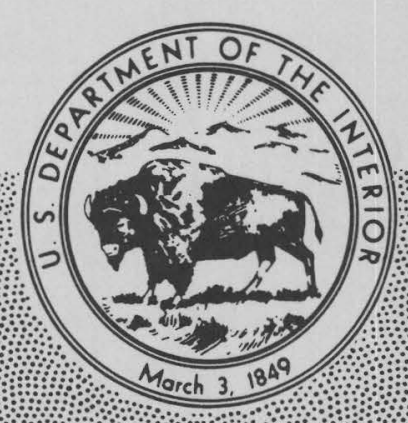

The Alaskan Mineral Resource Assessment Program: Background Information to Accompany Folio of Geologic and Resource Maps of the Chignik and Sutwik Island Quadrangles, Alaska 



\section{The Alaskan Mineral Resource}

Assessment Program: Background Information to Accompany Folio of Geologic and Resource Maps of the Chignik and Sutwik Island Quadrangles, Alaska

By R. L. Detterman, J. E. Case, D. P. Cox, D. E. Detra, T. P. Miller, and F. H. Wilson

GEOLOGICAL SURVEY CIRCULAR 802 
United States Department of the Interior JAMES G. WATT, Secretary

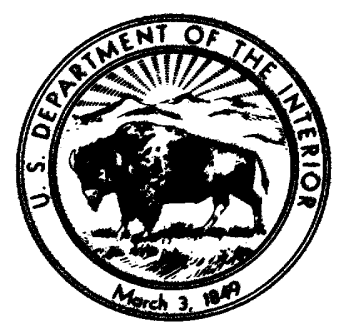

Geological Survey

Doyle G. Frederick, Acting Director

Library of Congress Cataloging in Publication Data

The Alaskan mineral resource assessment program

(Geological Survey Circular 802)

Bibliography: p. 13-16.

Supt. of Docs. no.: I 19.4/2:802

1. Mines and mineral resources--Alaska. I. Detterman, Robert L. II. Series.

QE75.C5 no. 802 [TN24.A4] $\left.\begin{array}{c}557.3 s \\ {\left[553^{\prime} 09798^{\prime} 4\right]}\end{array}\right)$ 81-607821




\section{CONTENTS}

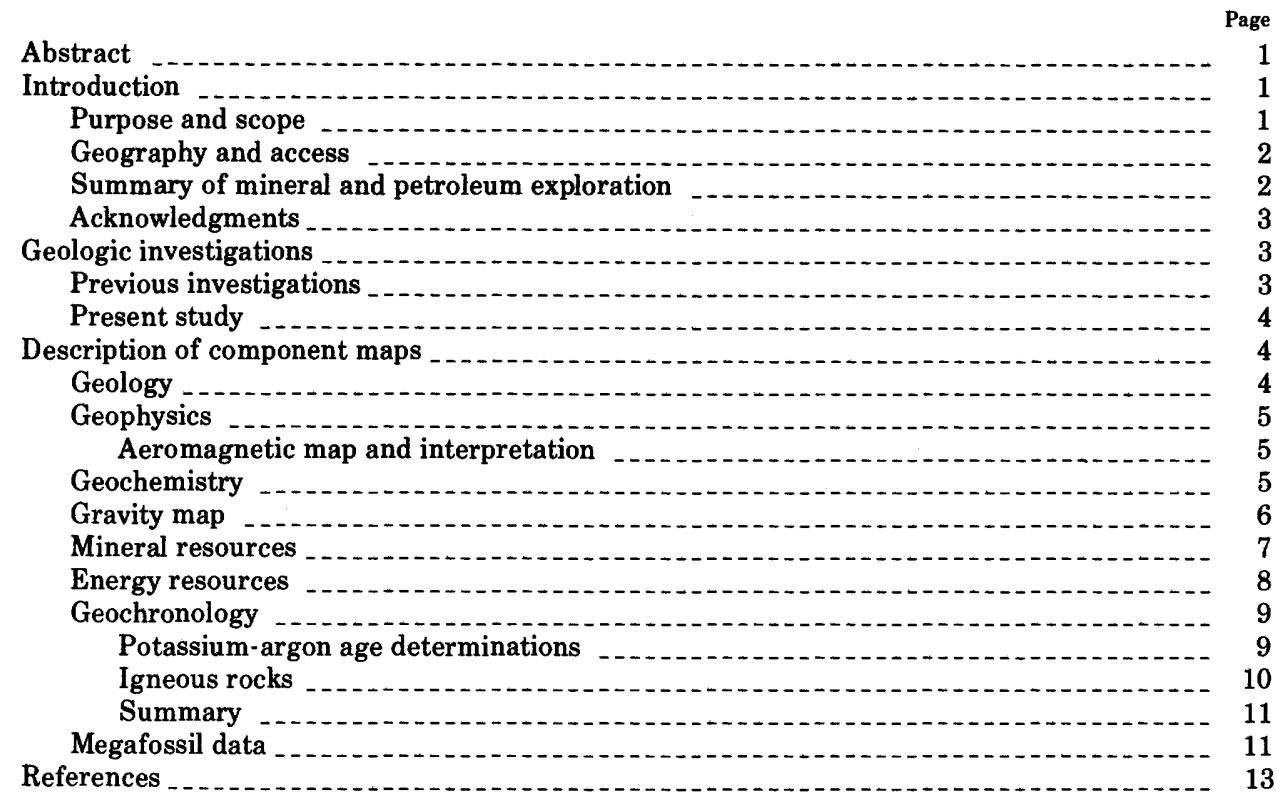

\section{ILLUSTRATION}

\section{TABLE}





\title{
The Alaskan Mineral Resource Assessment Program: Background Information to Accompany Folio of Geologic and Resource Maps of the Chignik and Sutwik Island Quadrangles, Alaska
}

\author{
By R. L. Detterman, J. E. Case, D. P. Cox, D. E. Detra, T. P. Miller, and F. H. Wilson
}

\section{ABSTRACT}

The Chignik and Sutwik Island quadrangles $(1: 250,000)$ are a part of the Alaska Peninsula in southwestern Alaska. This circular and a companion folio of maps represent results of integrated field and laboratory studies by an interdisciplinary team on geology, geophysics, geochemistry, mineral resources, geochronology, and energy resources to provide a modern assessment of the mineral and energy resources of the quadrangles. The maps contain descriptive text, explanatory material, tables and diagrams, and pertinent references. This circular provides the background data for the mineral and energy resource assessment and integrates the component maps. A comprehensive bibliography cites both specific and general references relevant to the geology and resources of the quadrangles.

\section{INTRODUCTION}

\section{PURPOSE AND SCOPE}

This circular and the companion folio of related maps are a part of the series of U.S. Geological Survey reports designed to provide a rapid and accurate inventory of Alaska's mineral resources. The reports furnish information for minerals and energy policy-making decisions by Federal, State, and industry concerning the future use of Alaskan land and resources. This report was prepared under the auspices of the Alaska Mineral Resource Assessment Program (AMRAP) by an interdisciplinary team of earth scientists. Field and laboratory studies were conducted during 1977 and 1978.

The folio consists of 15 maps that provide information on the geology, geochemistry, geophysics, geochronology, minerals, and energy resources of the Chignik and Sutwik Island quadrangles (table 1). The primary intent of the folio and circular is to furnish mineral- and energyresource data for land-use planning and sound long-term national resource policy. Additional aims are to increase the geologic knowledge of an active continental margin and to determine the time and type of mineral emplacement. This circu- lar contains an extensive bibliography relevant to the geologic aspects of the Chignik and Sutwik Island quadrangles, their mineral and energy resources, geochronology, and paleontology. Individual maps in the folio contain references applicable to their subject matter.

In addition to the folio maps, which are printed in black and white, two companion multicolored Miscellaneous Geologic Investigations Maps of the Chignik and Sutwik Island quadrangles (Detterman and others, 1981) are in press.

TABLE 1.-Component maps of the Chignik and Sutwik I sland quadrangles mineral and energy resource assessment

U.S. Geological Survey Miscellaneou Field Studies (MF) Map

\begin{tabular}{|c|c|}
\hline $\begin{array}{l}\text {-I (Tripp and Detra, 1980) } \\
\text {-J (Case and others, 1981) } \\
\text {-K (Cox and others, 1981) } \\
\text {-L (Detterman and others, 1981) } \\
\text {-M (Wilson and others, 1981) } \\
-\mathrm{N} \text { (Detterman and others, 1981) }\end{array}$ & $\begin{array}{l}\text { Geochemical distribution } \\
\text { and abundance of cop- } \\
\text { per. } \\
\text { Geochemical distribution } \\
\text { and abundance of lead. } \\
\text { Geochemical distribution } \\
\text { and abundance of zinc. } \\
\text { Geochemical distribution } \\
\text { and abundance of } \\
\text { molybdenum. } \\
\text { Geochemical distribution } \\
\text { and abundance of silver } \\
\text { and arsenic. } \\
\text { Geochemical distribution } \\
\text { and abundance of bis- } \\
\text { muth, } \\
\text { tin, and tungsten. } \\
\text { Mineralogy of heavy. } \\
\text { mineral concentrates. } \\
\text { Gravity map. } \\
\text { Mineral resources map } \\
\text { Energy resources map } \\
\text { Geochronology map } \\
\text { Fossil locality map, } \\
\text { check lists, and } \\
\text { stratigraphic sections. } \\
\text { Landsat map }\end{array}$ \\
\hline
\end{tabular}

\section{GEOGRAPHY AND ACCESS}

The Chignik and Sutwik Island quadrangles include about $19,435 \mathrm{~km}^{2}$ on the Alaska Peninsula in southwestern Alaska, approximately 60 percent 
of which is water (fig. 1). The quadrangles are bounded by $56^{\circ}$ and $57^{\circ} \mathrm{N}$. latitude parallels and by $156^{\circ}$ and $160^{\circ} 34^{\prime} \mathrm{W}$. longitude. The area is dominated by the massive volcanic edifice of Mount Veniaminof and other mountains of the Aleutian Range along the south edge and by Aniakchak Volcano on the north border. The Aleutian Range borders the Pacific Ocean, and most of the peaks are less than $1,000 \mathrm{~m}$ in elevation but rise nearly vertically from the ocean; Mount Veniaminof $(2,507 \mathrm{~m} ; 8,225 \mathrm{ft})$ is the highest peak. The Aleutian Range steeply drops off to the west onto the nearly flat Bristol Bay Lowland, which is mostly less than $30 \mathrm{~m}$ in elevation. The lowland bordering Bristol Bay is dominated by the spectacular caldera of Aniakchak Volcano, $9.5 \mathrm{~km}$ in diameter. The caldera contains a $3-\mathrm{km}$-long lake and several cinder cones, the largest of which is $580 \mathrm{~m}$ high.

Streams draining into the Pacific Ocean are generally short and have steep gradients, whereas most streams draining to Bristol Bay are shallow and sluggish because they are choked with pumice and glacial debris. The Meshik River is the largest stream and nearly crosses the peninsula; it follows a former arm of Bristol Bay that probably cut across the peninsula prior to the last major eruption of Aniakchak Volcano about 3,300 to 3,500 years B.P. (Miller and Smith, 1977). Chignik and Black Lakes are remnants of another arm of the sea that was closed by pumice and glacial deposits from Mount Veniaminof. Most of the area between the lakes and Bristol Bay is $15 \mathrm{~m}$ or less in elevation.
Population in the quadrangles is spare and fluctuates considerably with the fishing season. It is concentrated almost entirely around the villages of Meshik, Chignik, Chignik Lagoon, Chignik Lake, and Chignik Flats. There is scheduled air transportation into Port Heiden and Port Moller, and all the villages have landing strips for small planes. A few miles of gravel roads are in use at the abandoned Port Heiden Air Force Base.

\section{SUMMARY OF MINERAL AND PETROLEUM EXPLORATION}

Exploration for minerals and petroleum in the quadrangles by industry has revealed no large economic deposits to date. Coal is the only mineral resource ever mined and used commercially within the area. It was mined for a number of years in the early part of this century at the Chignik River and Whalers Creek mines (Atwood, 1911) for use in canneries at Chignik Lagoon and Anchorage Bay. The amount and value of the coal produced are not known.

Early mineral exploration in the quadrangles was mainly centered on large alteration areas sur. rounding porphyry stocks. Claims were staked and some exploration was done between 1900 and 1910 on deposits at Warner Bay, Mallard Duck Bay, and Nakchamik Island where copper, lead, zinc, and molybdenum minerals and gold are present. Exploration at all localities was small scale and sporadic; at Warner Bay it continued until the early 1960's. Modern exploration started in 1964 when Pan American Oil Company did extensive diamond drilling on a molybdenum-copper pros-

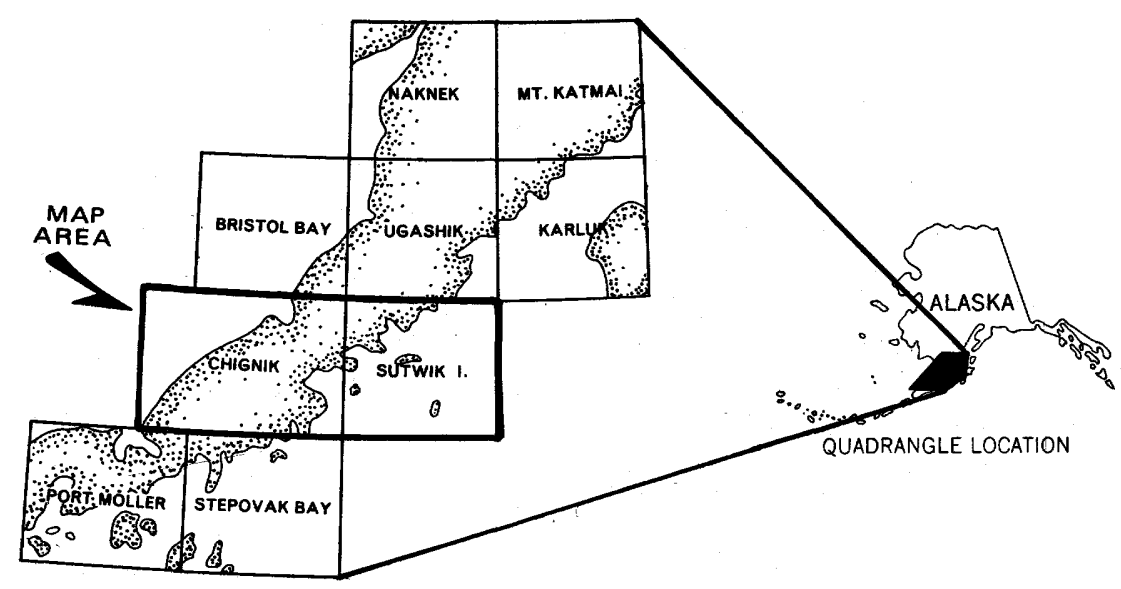

Figure 1. - Location of Chignik and Sutwik Island quadrangles, Alaska. 
pect in the mountains between the head of Braided and Cathedral Creeks. Interest in young porphyry copper deposits revived the drilling program in 1975 and 1976 when Bear Creek Mining Company drilled several holes on a prospect at the head of a tributary of Dry Creek and on Home Creek at the head of Mallard Duck Bay. Copper was the main mineral commodity of interest at both localities, but the concentration apparently is not high enough to warrant development under current conditions.

The thick sedimentary rock sequence exposed in the mountains has been of great interest to the petroleum industry. Starting in the 1950's, many major companies investigated the area in detail. The exposed rocks are cut by stocks, plugs, dikes, and sills, some of which are related to the volcanoes, but some good reservoir and source rocks are present. Two wells were drilled on the Bristol Bay lowland where it was hoped that the beds would not have been altered by the intrusive rocks. Gulf Oil Corporation's Sandy River Federal well was completed in 1963 to a depth of $3,983 \mathrm{~m}$ $(13,068 \mathrm{ft})$. Numerous shows of oil and gas were found below $3,000 \mathrm{~m}$ in the upper part of the Tolstoi Formation and the lower part of the Bear Lake Formation. Good porosity and permeability of the sandstone associated with oil and gas shows are encouraging for potential petroleum resource development. The Gulf Oil Corporation Port Heiden Unit drilled in 1972 to a depth of 4,576.5 $\mathrm{m}(15,015 \mathrm{ft})$, was dry.

\section{ACKNOWLEDGMENTS}

Geologic investigations in the Chignik and Sutwik Island quadrangles were facilitated greatly by the efforts of many geologists from the U.S. Geological Survey and private industry whose many contributions are gratefully acknowledged. The work of some visiting scientists, short-term workers, and laboratory specialists is acknowledged on individual maps in the folio. The contributions of some specialists, although not mentioned specifically on the maps, were of great benefit to the project. Among those to whom special tribute is due are J. A. Wolfe, R. A. Spicer, D. L. Jones, Louie Marincovich, J. W. Miller, and R. W. Imlay, all paleontologists with the U.S. Geological Survey whose identifications of many collections of invertebrate and plant fossils helped unravel the stratigraphic succession of sedimentary units. R. L. Smith and D. H. Richter made a significant contribution to an understanding of the complex eruption history of Veniaminof and Aniakchak Volcanoes.

The assistance of many people from private industry engaged in minerals and petroleum exploration is appreciated, particularly that of E. D. Fields, William Polski, Scott McCoy, A. W. Erxleben, and C. M. Molenaar. Special thanks are also due W. C. Bishop and the Bristol Bay Native Corporation for giving us permission to work in the area, and for making data available from the drilling program on the copper prospects of the Bear Creek Mining Company.

Work in a remote area such as the Alaska Peninsula would be impossible without the able assistance of local residents. Among those who were of great service to the project were the people at Columbia Ward Fisheries at Chignik Lagoon, especially Ben Bender, who provided the project with food and lodging during 1977 and 1978 and aided in many phases of the logistic support that made completion of the project possible.

Special thanks and commendation are due Captain Roy Roebeck and the crew of the U.S. Geological Survey Research Vessel Don J. Miller $I I$, who cheerfully provided us with a base of operations for part of 1977 and 1978. Also, to R. W. McDonald of ERA Helicopters and Gordon Hines of Air Logistics Helicopter Company, who often flew in adverse weather to take us to our work sites.

\section{GEOLOGIC INVESTIGATIONS}

\section{PREVIOUS INVESTIGATIONS}

The first geologic publication covering, in part, the area of this report on the Alaska Peninsula, was a remarkable compilation by Grewingk (1850). For many years his interpretation and analysis of the stratigraphy and structure were the basis for the geologic interpretations of this part of Alaska. Other important generalized contributions to the geology of this part of Alaska were made by Dall and Harris (1892) and Dall (1896).

More detailed geologic investigations of the Chignik and Sutwik Island area were made by Atwood (1911) and Knappen (1929). Martin (1926) made the first major attempt at correlating the Mesozoic stratigraphic units of the Alaska Peninsula and showed how they related to those in the 
rest of Alaska. At about the same time, Smith and Baker (1924) made important contributions to the geology of the Chignik area, and Smith (1924) made the first detailed study of Aniakchak Crater.

The foundation for the modern interpretation of the stratigraphy and structure of the Alaska Peninsula, including the Chignik and Sutwik Island areas, was made by Burk (1965) during the late 1950's for the Richfield Oil Corporation (now a part of the Atlantic Richfield Company), one of the many major petroleum companies working on the peninsula at that time.

\section{PRESENT STUDY}

Fieldwork and laboratory analysis for the present study were started in 1977 and completed in 1978. T. P. Miller and R. L. Smith had started detailed mapping of Anialchak, Black, and Veniaminof Volcanoes in 1974 and 1975, and this work was continued during the present investigation. Most of the geologic mapping was at a detailed reconnaissance scale, but sufficient data were gathered in some areas to prepare 15minute $(1: 63,360)$ quadrangles. The geologic mapping and geochemical sampling were helicopter supported.

During the course of the investigation, 1,455 stations were occupied for geologic data; 637 stream-sediment samples and 623 heavy mineral pan-concentrate samples were collected. In addition, 448 bedrock samples were collected at geologic stations for analysis; these included both mineralized samples and unmineralized specimens for a background data base. Prior to the present study, only two potassium-argon dates were available for the Chignik and Sutwik Island quadrangles (Kienle and Turner, 1976; Armstrong, Harakal, and Hollister, 1976). A total of 40 new potassium- argon dates have been added by F. H. Wilson and M. L. Silberman; these dates permit a determination of the time of mineral emplacement (Wilson, 1981).

Gravity data were collected at many of the geochemical sampling sites. In 1977 they were obtained by M. E. Yount, C. D. Holloway, and D. E. Detra and in 1978 by D. R. Jefferis. The aeromagnetic interpretation map was compiled from data flown by LKB Resources, Inc. in 1977 on U.S. Geological Survey contract.

\section{DESCRIPTION OF COMPONENT MAPS OF THE CHIGNIK AND \\ SUTWK ISLAND QUADRANGLES FOLIO}

\section{GEOLOGY (MAP MF-1053-A)}

The Chignik and Sutwik Island quadrangles are a part of the Aleutian volcanic arc, a segment of an active continental margin. The modern Aleutian volcanic arc is nearly superimposed over an earlier Mesozoic magmatic arc. The oldest sedimentary rocks exposed in the quadrangles are of Middle Jurassic age and were deposited on a shelf area in an arc- trench gap basin (terminology of Dickinson, 1974) fronting (south of) the Mesozoic magmatic arc. Paleomagnetic data indicate that these rocks were deposited considerably south of their present latitude (Packer and Stone, 1974; Stone and Packer, 1979). Igneous activity had waned in the Mesozoic arc by the time the oldest sedimentary rocks were being deposited, and tectonic activity had uplifted some of the igneous rocks so that they were contributing to the sedimentary cycle. Deposition was continuous during Jurassic and into Early Cretaceous time, and the arc-trench gap basins were nearly filled. A period of crustal mobility followed during middle Cretaceous time, subjecting these basins to erosion so that the latest Cretaceous and early Tertiary rocks rest uncomformably on the older deposits.

The late Cretaceous through early Tertiary was a time of relative quiescence on the Alaska Peninsula. The Semidi Islands batholith was emplaced, and a few flows are present in the early Tertiary rocks, but the general absence of igneous activity suggests that subduction along this part of the continental margin had temporarily ceased. Igneous activity started again in late Eocene time and continued through at least part of the Oligocene with a flood of extrusive and hypabyssal intrusive rocks mainly of basaltic to andesitic character, which probably indicates renewed subduction along the continental margin. The Aleutian volcanic arc started with this pulse. Another quiet interval lasting about $15 \mathrm{~m} . \mathrm{y}$. spans the late Oligocene and early Miocene. Volcanic and associated intrusive activity greatly increased in late Miocene time and has continued to the present. The Miocene to Holocene volcanic rocks are 
mainly andesite and dacite. Detritus from these volcanic rocks has contributed to the severalthousand-meter thickness of volcaniclastic rock deposited in back-arc basins and deltas along the north side of the Alaska Peninsula.

Tectonic activity associated with subduction has resulted in numerous thrust and high-angle reverse faults mainly in the mountainous Pacific coast side of the peninsula where there has been considerable foreshortening and juxtaposing of stratigraphic units. Large scale transverse fracturing is also common. One such fracture trending $\mathrm{N}$. $40^{\circ} \mathrm{W}$. in the Mount Veniaminof area is marked by a cluster of cinder and spatter cones.

\section{GEOPHYSICS}

\section{AEROMAGNETIC MAP AND INTERPRETATION (MAP MF-1053-B, 2 sheets)}

The aeromagnetic survey of the Chignik-Sutwik Island quadrangles is one of the most detailed, systematic surveys made across a modern volcanic arc setting, where both Holocene volcanic edifices and possible older volcanic centers occur.

Four main groups of magnetic anomalies have been identified in the area. (1) Ovoid clusters of positive and negative anomalies occur over Holocene volcanic edifices at Mount Veniaminof, Black Peak, and Aniakchak Crater. (2) Ovoid clusters of positive and negative anomalies occur over volcanic- plutonic complexes near Kujulik Bay, Chiginagak Bay, Sutwik Island, and Nakchamik Island. Isotopic ages of igneous rocks from these older groups tend to fall into two ranges: 38-30 m.y. for the Kujulik Bay and Sutwik Island complexes and 10-5 m.y. for the Chiginagak Bay and Nakchamik Bay complexes. If the volcanic complexes are related to subduction in the Aleutian trench, the site of volcanism has remained nearly unchanged (within $\pm 75 \mathrm{~km}$ ) with respect to the present trench axis since 38 m.y. ago.(3) Large positive ovoid magnetic anomalies occur over Tertiary and Quaternary igneous rocks that range in age from $38 \mathrm{~m} . \mathrm{y}$. to about $1.0 \mathrm{~m} . \mathrm{y}$. These rocks are dioritic to granitic in composition and presumably are related to subduction in the Aleutian trench. Several of the plutons contain porphyry copper-molybdenum deposits, so that their distinctive aeromagnetic expression is a regional ore guide. Local areas of extreme hydrothermal alteration are expressed by flat magnetic gradients or by negative aeromagnetic anomalies, and such anomalies are a more specific ore guide. (4) Broad, gentlegradient anomalies occur over sedimentary basins on both the Bristol Bay side and Pacific side of the Alaska Peninsula. Local anomalies related to volcanic intercalations or small intrusions are superimposed on the deep basin anomalies. The basement is $2 \mathrm{~km}$, or deeper, on both the Bristol Bay and Pacific margins of the peninsula, but the basins are interrupted on both sides of the peninsula by volcanic-plutonic complexes that range in age from at least $38 \mathrm{~m} . \mathrm{y}$. to $1.0 \mathrm{~m} . \mathrm{y}$.

Chignik anticline, which might appear to be a favorable target for exploratory drilling for oil and gas, has a core of sedimentary rocks, but many small, high-amplitude magnetic anomalies in the core region indicate the presence of many small intrusive bodies or the presence of volcanic rocks of the Meshik Formation below thrust faults. Thus, the Chignik anticline should not be considered a major prospect for oil and gas exploration until much additional detailed geophysical work has been done.

\section{GEOCHEMISTRY (MAPS MF-1053-C TO I)}

A geochemical survey was made during the 1977 and 1978 field seasons. The data obtained from this survey provided plots showing abundance and distribution patterns of specific elements from which mineral occurrences of possible economic interest were outlined.

The geochemical investigation was conducted over an area covering $18,000 \mathrm{~km}^{2}$. Streamsediment samples were collected at 637 sites from the channels of active streams that were draining catchment areas approximately 8 to $12 \mathrm{~km}^{2}$ in area. The stream-sediment samples were dry sieved to minus-80 mesh and then analyzed for 30 elements using a semiquantitative emission spectrographic method (Grimes and Marranzino, 1968). In addition, a fraction of the minus - 80 mesh fraction was analyzed for copper, lead, and zinc by atomic absorption (Ward and others, 1969).

Heavy-mineral concentrates were made from stream sediment at 623 of the sample sites. A nonmagnetic fraction was obtained from the 
heavy-mineral concentrate samples and analyzed for 31 elements by semiquantitative emission spectrography (Grimes and Marranzino, 1968). Analytical data, a comprehensive description of sample preparation and analysis, and a statistical summary of these results, for stream-sediment and heavy-mineral concentrate samples, have been presented in an Open-File Report (Detra and others, $1978 \mathrm{a}, \mathrm{b}$ ).

The distribution and abundance of copper,lead, zinc, molybdenum, silver, arsenic, bismuth, tin, and tungsten in nonmagnetic heavy-mineral concentrate and minus- 80 mesh stream-sediment samples are presented on Miscellaneous Field Studies Maps that accompany this circular (Detra and others, 1980 a,b,c). Maps showing the distribution of selected minerals found in the nonmagnetic fraction of heavy-mineral concentrate samples are also presented (Tripp and Detra, 1980).

The nonmagnetic fraction of heavy-mineral concentrate samples proved to be the most useful sample medium for outlining potential mineral occurrences because dilutional effects produced by the presence of common rock-forming minerals and barren rock fragments making up the bulk of the stream sediment are significantly reduced. The isolation of this heavy-mineral fraction effec. tively improved the contrast between background and anomalous values obtained by spectrographic analysis.

An effort was made to determine background concentrations of specific elements in the major rock units as described on the geologic map (Detterman and others, 1979). Representative rock samples were collected and analyzed using the semiquantitative spectrographic method. Statistical data based on the analytical results appear, where applicable, on the element plots (Detra and others, 1980). The intended purpose is to provide a basis of comparison between the anomalous ranges of element content determined for stream sediments and heavy-mineral concentrates and that of the source rocks from which the sediment was derived.

The most significant anomaly patterns on the geochemical maps outline occurrences of copper, molybdenum, zinc, and other associated elements of interest. Some specific localities are Cape Kumlik, Cathedral Creek, and Warner Bay areas, where mineralization is associated with Tertiary intrusive rocks.
The simple Bouguer anomaly map of the Chig. nik and Sutwik Island quadrangle is dominated by several northeast-trending gravity highs having values of +30 to more than +50 mgals. A relative gravity low having values of 0 to-10 mgals occur over the Bristol Bay Basin in the Bristol Bay Lowlands. According to Barnes' gravity anomaly map (1977), Bouguer anomalies offshore in Bristol Bay to the northwest are about +20 to +30 mgals, so the residual gravity low over the basin is about 30 mgals with respect to the Bristol Bay shelf. From the positive anomaly over the peninsula, gravity values decrease southward to values of +20 mgals at Sutwik Island, to +10 mgals at the Semidi Islands, and to -30 mgals near the east edge of the map. Immediately southeast of the map area, over the Shumgin Basin, which contains as much as $2 \mathrm{~km}$ of stratified sedimentary rocks, Bruns and von Huene (1977) reported a gravity low of about -20 mgals. Separating the gravity low of the Bristol Bay Lowlands from the high over the mountainous parts of the peninsula is a major northeast-trending zone of steepened gravity gradient that reflects a major late Tertiary tectonic boundary that may represent a rejuvenated feature as old as Jurassic (Bruin Bay fault).

The general gravity low over the basin beneath the Bristol Bay Lowlands is consistent with the great thickness of Tertiary sedimentary rocks that occurs in the basin. Drill holes have penetrated about 4,000-4,500 m of Tertiary sedimentary and volcanic rocks.

Southwest of Mount Veniaminof, a positive gravity nose, having values greater than +50 mgals, is the northeast end of a major gravity high that extends far to the southwest along the Alaska Peninsula and continues into the Aleutian Islands (Barnes, 1977). Values in excess of +80 mgals to the southwest strongly suggest that the crust is oceanic rather than continental.

A second major gravity high coincides very closely with the Chignik anticline. Structural relief, for example at the base of the Tertiary rocks, across the southeast flank of the anticline is as much as 3,000 $\mathrm{m}$ from Castle Bay to the anticlinal crest (Burk, 1965, fig. 22), and structural relief from the Port Heiden well in the Bristol Bay Lowlands to the crest of the anticline (where Jurassic strata are exposed) is at least $5,500 \mathrm{~m}$ and may be $7,500 \mathrm{~m}$ or more. Again, simple Bouguer 
anomalies in excess of +50 mgals are suggestive of oceanic rather than continental crust, especially where the stations are in mountainous terrane.

One of the more significant anomalies of the area, from a mineral resource viewpoint, is a negative anomaly of -10 to $-15 \mathrm{mgals}$ in the Warner Bay-Devils Bay-Kuiukta Bay region in the southeast part of the Chignik quadrangle that generally coincides with the complex of granitic plutonic rocks of the area. The granitic rocks contain copper and molybdenum mineralization at several localities, especially at Warner Bay. It seems evident that the granitic rocks, which have been extensively altered, are considerably less dense than the adjacent rocks that they intrude; wallrocks include considerable hornfels.

No deep crustal refraction measurements have been made in this part of Alaska, so the gravity data provide the main geophysical basis for speculation about crustal composition and thickness. The strongly positive gravity anomalies over the Aleutian Islands extend northeast along the peninsula to about lat $58^{\circ} \mathrm{N}$., near Becharof Lake, in the Ugashik quadrangle. A major negative anomaly in the vicinity of Katmai National Park continues northeastward into Cook Inlet and beyond to the Matanuska Valley (Barnes, 1977). Using the empirical relations between Bouguer anomalies and mean elevation, derived by Woollard and Strange (1962) and Deminitskaya and Belyaevsky (1969), we suggest that oceanic crust forms the pre-Triassic basement of the peninsula south of Becharof Lake and continental or transitional crust north of Becharof Lake.

\section{MINERAL RESOURCES MAP (MAP MF-1053-K)}

Many areas within the Chignik-Sutwik Island quadrangles have a high potential for discovery of porphyry copper-molybdenum deposits. One such deposit called Bee Creek was drilled in 1976 by Bear Creek Mining Company in cooperation with Bristol Bay Native Corporation, and the drill core and drilling records were made available to the U.S. Geological Survey for study. At Bee Creek, disseminated chalcopyrite and molybdenite are associated with intense biotite alteration of arkosic graywacke of the Jurassic Naknek Formation intruded by a small quartz diorite stock. Although the prospect has all of the characteristics of a porphyry-type deposit (intense fracturing, biotite alteration, abundant halite-bearing fluid inclusions), both tonnage and metal grade, as revealed by drilling, are low, and no further work has been done. Five other mineral occurrences suggesting porphyry- type deposits are known in the two quadrangles.

Studies of the distribution of metallic elements in fine-grained stream sediments and nonmagnetic heavy-mineral concentrates of stream sediments have revealed significant anomalies in arsenic, bismuth, copper, gold, lead, molybdenum, silver, tin, tungsten, and zinc. When these metal anomalies were plotted on the map within the drainage areas in which they occur, a distinct clustering was evident, and metal anomalies within clusters were found to be distributed in a zonal order. Molybdenum, copper, and locally, tungsten anomalies occur in centrally located drainage areas that are flanked or surrounded by drainage areas containing anomalous copper, lead, zinc, arsenic, silver, or gold. Some clusters have an outer fringe of drainage areas containing anomalous bismuth and tin.

Centrally located copper and molybdenum anomalies coincide with the Bee Creek deposit and five other porphyry-type mineral occurrences. Seven other copper-molybdenum anomalies are suspected to have been derived from concealed or otherwise undetected porphyry-type mineral occurrences.

Flanking and peripheral metal anomalies are believed to be derived from small veins deposited in a zonal pattern around volatile-rich igneous plutons where porphyry-type mineralization may have taken place. The zoning of the groups of elements is caused by the stability of their sulfide minerals in hydrothermal fluids at decreasing temperatures relative to increasing distance from the plutonic-hydrothermal heat source.

The zoning patterns revealed in this study indicate that the hydrothermal mineralization effects of volatile-rich plutons may extend outward as much as $10 \mathrm{~km}$. The zoning patterns also indicate that most, if not all, anomalies of the 10 metals cited above are due to hydrothermal activity, and the presence of deposits of these metals formed by other processes can be effectively ruled out. Finally, recognition of 13 distinct clusters of anomalies with copper-molybdenum-rich central zones makes it possible to narrow the probability limits associated with estimates of the number of undiscovered porphyry deposits in the study area. 
The possibility of sedimentary uranium deposits in the Chignik and Sutwik Island quadrangles cannot be disregarded even though no supporting mineralogic or geochemical evidence for such deposits was revealed in this study. The sedimentary and structural environments of the Chignik (Cretaceous), Tolstoi (Paleocene and Eocene), and Bear Lake (Miocene) Formations were compared with the Regional Western States Sandstone Uranium Model (Racklay, 1976) using the PROSPECTOR computer model implemented by John Gaschnig at Stanford Research Institute (see Gaschnig, 1980). Both the Chignik and Tolstoi Formations received high values for favorability for occurrence of roll-front type uranium deposits. Unfavorable features were the absence of direct evidence of mineralization and the degree of structural tilting and folding of the units. The dacitic to andesitic composition of tuff beds interlayered with these units may also be an unfavorable feature since most uranium deposits are genetically associated with more felsic tuffaceous deposits.

Values resulting from application of this program to field data from the study area are expressed as degree of certainty with which the field data fit the model. A perfect fit is +5 , insufficient information is zero, and a perfect nonfit is -5 . Values for the three formations are as follows:

\begin{tabular}{lccc} 
& $\begin{array}{c}\text { Chignik } \\
\text { Formation }\end{array}$ & $\begin{array}{c}\text { Tolstoi } \\
\text { Formation }\end{array}$ & $\begin{array}{c}\text { Bear } \\
\text { Lake } \\
\text { Formation }\end{array}$ \\
$\begin{array}{l}\text { Favorable tectonic } \\
\text { and other regional } \\
\text { conditions }\end{array}$ & 3.59 & 4.01 & 4.32 \\
$\begin{array}{l}\text { Favorable sedimentary } \\
\text { environment }\end{array}$ & 4.81 & 4.68 & 3.64 \\
$\begin{array}{l}\text { Favorable } \\
\text { mineralization and } \\
\text { alteration }\end{array}$ & 1.08 & .58 & .19 \\
\hline
\end{tabular}

Overall favorability

for Western States sandstone uranium deposits _.

\section{ENERGY RESOURCES (MAP MF-1053-L)}

Energy resources investigations of the Chignik and Sutwik Island quadrangles included: detailed measurement of selected representative sections of sedimentary rock to determine origin, depositional environment, and post-depositional alteration; collection of samples for porosity, permeability, organic carbon, total carbon, and degree of maturation as an indication of their petroleum potential; mapping the location and extent of all coal and carbonaceous shale beds and collection of samples for analysis; investigation of the Holocene volcanic centers as potential geothermal sites.

Sections of the Naknek, Chignik, Tolstoi, and Bear Lake Formations were measured in detail; other sections are generalized. These stratigraphic units are the main sandstone sequences that could be potential source or reservoir rock. The lower sandstone unit of the Naknek Formation is about 68 percent arkosic sandstone mainly of fluvial, fluvial deltaic, and beach depositional environment. Samples checked for porosity and permeability were uniformly low - about 1.1 percent porosity and 0.01 md permeability. Post depositional diagenesis is the main cause of the low values in the Naknek Formation. The foreshore to fluvial deltaic cyclic sequence of the Chignik Formation produced sandstones with somewhat better values; the range in porosity was from 1.0 to 8.0 percent and permeability from 0.20 to 2.06 md. A typical section at Chignik Lagoon (Detterman, 1978) is about 56 percent sandstone and conglomerate. The few samples collected from the Tolstoi Formation had about the same range as the Chignik samples. By far, the highest values were found in the few samples collected from the Bear Lake Formation. Ranges were from 15.1 to 18.2 percent porosity and 333 to 520 md permeability.

Shale and siltstone samples from the Chignik, Hoodoo (Cretaceous), and Tolstoi Formations were analyzed for carbon content and degree of maturation. The carbon content of samples from the Chignik ranged between 0.53 and 29.65 percent, values for the Hoodoo were 0.48 to 9.82 , and those for the Tolstoi ranged between 4.93 and 8.87 percent. Maturation data have not been determined, but coal from the Chignik Formation is classified as high-volatile B bituminous (Conwell and Triplehorn, 1978), which indicates a degree of maturation that would produce oil and gas. The presence of oil-saturated sandstone in the Chignik Formation at Chignik Lagoon (Keller and Cass, 1956) indicates that hydrocarbons have been generated.

Coal beds crop out throughout the area underlain by rocks of the nonmarine cycles of the Chignik and Tolstoi Formations. Most of the coal occurs in beds 0.3 to $1 \mathrm{~m}$ thick, generally with three 
to five beds separated by shale and bone at any one locality. Beds are locally as thick as $3 \mathrm{~m}$. Analysis of coal from the Chignik Formation (Conwell and Triplehorn, 1978) indicates that it is high-volatile $\mathrm{B}$ bituminous with a high ash content and a BTU value of about 12,000 . Coal from the Tolstoi Formation is untested but appears to be of slightly lower grade.

Carbonaceous shale, also, is common throughout the Tolstoi Formation, and thin seams of coal and carbonaceous shale are found in parts of the Bear Lake Formation.

The rank of the coal in the Chignik Formation indicates a degree of maturation that would produce oil and gas in the same rocks provided that a source were present; the analyses of the samples suggest that a source exists. The point of maximum oil and gas generation occurs at the same point that produces high-volatile B bituminous coal (Dow, 1977). Local oil staining of sandstone of the Chignik Formation at Chignik Lagoon indicates that some petroleum has been generated. However, the chance of finding a major oil field is greatly reduced by the presence of numerous stocks and plugs intruded into the sedimentary sequence. Interpretation of the aeromagnetic map (MF-1053-B, Case and others, 1981, this folio) indicates that intrusive rocks probably are present in the core of some structures.

Four large volcanic centers of Quaternary age occur in the Chignik- Sutwik Island study area, and at least three have high potential for geothermal energy. Aniakchak and Veniaminof Volcanoes are caldera systems whose youthfulness, size, and past volcanic history strongly indicate a large, near-surface heat reservoir. Smith and Shaw (1975) have calculated a heat content of $129 \times 10^{18}$ cal for Aniakchak Volcano and $115 \times 10^{18}$ cal for Veniaminof Volcano.

Black Peak is a smaller volcanic center that, however, represents a very long-lived igneous system with recent volcanic activity from a nearsurface magma chamber. The heat content associated with this chamber has been estimated at $12 \times 10^{18}$ cal by Smith and Shaw (1975).

Kupreanof Volcano, although not yet completely mapped, appears to be a large stratovolcanic complex that, unlike the other three volcanic centers, has not yet been the site of explosive silicic volcanism. The occurrence of at least two major sites of fumarolic activity and recent silicic dacitic flows may indicate that a near-surface magma' chamber is forming with a resulting reservoir.

\section{GEOCHRONOLOGY (MAP MF-1053-M)}

\section{POTASSIUM-ARGON AGE DETERMINATIONS}

As part of the Chignik-Sutwik Island AMRAP project, potassium-argon studies of igneous rocks were undertaken. Two strategies were used in dating: (1) dating of primary minerals or whole rocks to determine crystallization ages and (2) dating of secondary or hydrothermal minerals to determine the time of alteration and mineralization.

For whole-rock samples, other than quartzsericite samples, preparation was by crushing to 60-100 or 100-200 mesh, depending on mineral grain size, followed by a hydrofluoric acid leaching. The leaching process removes secondary minerals and glass and etches the remainder. Experimentally, this procedure has been shown to dramatically increase the relative percent radiogenic argon in the sample while apparently not affecting the determined age (M. L. Silberman, oral commun., 1978). This measurably decreases the analytical error in the age determination.

Rocks that were to be processed to yield mineral separates were crushed, washed, separated using methylene iodide for density separation, a Franz Isodynamic Separator ${ }^{1}$ for magnetic separation, and a vibrating inclined table for separation of platy minerals. Purities of the mineral separates in most cases exceeded 99 percent. Splits of these separates were then made for potassium analysis and argon extraction.

Argon extraction and mass spectrometry were carried out in the U.S. Geological laboratories in Menlo Park, California, generally following the methods of Dalrymple and Lanphere (1969). Paul Klock was the potassium analyst, and all analyses were made by flame photometry using a lithium metaborate flux and lithium internal standard (Engels and Ingamells, 1970). All potassium analyses were in duplicate, and most were in quadruplicate.

${ }^{1}$ Any use of trade names is for descriptive purposes only and does not imply endorsement by the U.S.Geological Survey. 
As of July, 1976, all potassium-argon age determinations from the U.S. Geological Survey are reported using the following new isotope abundance and decay constants:

$$
\begin{aligned}
\lambda_{\epsilon} & =5.72 \times 10^{-11} \text { year }^{-1} \\
\lambda_{\epsilon^{\prime}} & =8.78 \times 10^{-13} \text { year }^{-1} \\
\lambda_{\beta} & =4.93 \times 10^{-10} \text { year }^{-1} \\
{ }^{40} \mathrm{~K} / \mathrm{K} \text { total } & <1.167 \times 10^{-4} \mathrm{~mol} / \mathrm{mol}
\end{aligned}
$$

(Beckinsale and Gale, 1969; Garner and others, 1975). The age equation resulting from use of these constants is:

$$
\mathrm{t}_{(\mathrm{yrs})}=1.804 \times 10^{9} / \mathrm{n}\left(9.541\left({ }^{40} \mathrm{Ar} /{ }^{40} \mathrm{~K}\right)+1.0\right) .
$$

For ages between 1 and $100 \mathrm{~m} . \mathrm{y}$. this change adds approximatly 2 percent to ages calculated using the previous constants.

\section{IGNEOUS ROCKS}

Intrusive rocks in the area range in age from Paleocene to Quaternary. The igneous terminology used here follows that of Streckeisen (1976, 1979). Many hypabyssal rocks are plutonic in form and texturally intermediate between volcanic and plutonic; volcanic names are used for these. Compositionally they range from leucobasalt to dacite, although the bulk are near andesite in composition. Most intrusive rocks are hypabyssal; relatively deep seated plutons are represented by three major occurrences; (1) the large late Miocene quartz diorite( ?) body extending along the coast to the northeast from Chiginagak Bay in the Sutwik Island and Ugashik quadrangles; (2) the Devils batholith, a late Miocene granodiorite to tonalite multiphase intrusive body south of Chignik centered on Devils Bay in the Chignik quadrangle; and (3) the Paleocene biotite granodiorite (Kienle and Turner, 1976) in the Semidi Islands in the Sutwik Island quadrangle. Minor occurrences of plutonic rocks include a number of small tonalite bodies at Mallard Duck Bay.

The exposed intrusive rocks of the study area can be considered the roots of eroded volcanoes, and as such they tend to be saturated with silica and poor in alkali. The intrusive rocks commonly are closely associated with volcanic rocks. The major mafic mineral is hornblende, though pyroxene and biotite are also present. No rocks, other than eroded debris of the Alaska-Aleutian Range batholith, were found to contain primary muscovite. Primary biotite and potassium feldspar are rare in all but the Devils batholith.

The volcanic rocks mapped as the Meshik Formation are dacitic to leucobasaltic flows, agglomerates, and breccias. These are usually hydrothermally altered, although in a number of areas, fresh, columnar- jointed andesite and dacite plugs are included in the formation. Several of these plugs have been dated at 35 to $30 \mathrm{~m} . \mathrm{y}$., thereby providing a probable upper limiting date on the formation. The samples dated range in composition from hornblende dacites to two pyroxene andesites.

In several areas, particularly on Cape Kumlik and Kumlik Island, hypabyssal hornblende leucobasalt and andesite porphyry plutons intrude sedimentary rocks of the Tolstoi Formation. Potassium-argon ages of these intrusions, all of which cluster about 35 m.y. (Oligocene) (samples $77 \mathrm{AWs} 30,40,46,74,78 \mathrm{AWs} 17,18$, and 24 ), indicate that the intrusions may be the roots of volcanoes that were sources for some of the volcanic rocks of the Meshik Formation. The previously mentioned dacite and andesite plugs may also be necks of volcanoes that were sources for some of the Meshik Formation.

On Cape Kumlik and Kumlik Island, several hypabyssal hornblende andesite and leucobasalt pophyry intrusives are found. Each of these rocks is associated with areas of extensive alteration and possible mineralization. Phenocrystic amphibole is the dominant mafic mineral in all of these rocks; however, a few samples contain relicts or pseudomorphs of pyroxene. The groundmasses of these rocks are fine grained and are composed of plagioclase feldspars and opaque minerals. Potassium-argon age determinations on the amphiboles range from $39.1 \pm 2.54$ to $34.2 \pm 2.07$ m.y. (Eocene and Oligocene), indicating that the hypabyssal bodies are approximately coeval with the Meshik Formation.

Similar to these rocks are the intrusive rocks found on Cape Kunmik. At Cape Kunmik, autoliths of pyroxene and amphibole are quite common and from a distance give the rock a porphyritic appearance. Mineralization and alteration of the surrounding country rocks are not so extensive as at Cape Kumlik. A potassium-argon age of $33.5 \pm 2.33$ m.y. (Oligocene) has been determined on a green pleochroic amphibole from a 
hornblende andesite where the plagioclase is so altered as to be virtually unrecognizable.

A very strongly altered rock mass that was apparently a biotite-hornblende dacite dome was found on the northwest side of Sutwik Island. This is one of the few rocks in the study area with primary biotite. Alteration of the plagioclase is such that the composition is indeterminate; hornblende has been resorbed or altered to calcite and opaques. Quartz is common and apatite is extremely abundant. The biotite appears quite fresh and has yielded a potassium-argon age of 34.5 土1.66 m.y. (Oligocene).

Pinnacle Mountain, near Meshik Lake, is a hornblende andesite(?) porphyry pluton intruding the Tolstoi and Meshik Formations. The texture is porphyritic, and the fine-grained groundmass composes about 50 percent of the rock. A potassium-argon age of $34.5 \pm 0.85 \mathrm{~m} . \mathrm{y}$. was determined on hornblende from this rock.

A plagioclase separate from a two-pyroxene andesite from near Nakalilok Bay in the Sutwik Island quadrangle yielded an age of $48.1 \pm 0.89 \mathrm{~m} . \mathrm{y}$. The texture is porphyritic; plagioclase composes the bulk of the phenocrysts and pyroxene primarily in the groundmass.

Throughout the study area are many intrusive and volcanic rocks of late Tertiary age, particularly near presently active volcanoes. These include numerous volcanic rocks around Mount Veniaminof, most of the small intrusive bodies associated with alteration zones, and other scattered intrusive bodies in the northeastern part of the Sutwik Island quadrangle.

Most of the small intrusive bodies are petrographically similar. Either phenocrystic hornblende and (or) hypersthene or augite are the mafic mineral(s); they have resorted edges and are probably partially chloritized. The plagioclase, where it can be determined, is of An45-55 composition, and is usually much altered. Quartz may or may not be present in the groundmass or as phenocrysts. The texture is porphyritic with a fine-grained to aphanitic groundmass and phenocrysts of plagioclase and the mafic mineral.

A hornblende separate from a sample of an andesite sill collected at Anchorage Bay near Chignik yielded a $16.5 \pm 1.48$ m.y. age. The dated sample is hydrothermally altered, with strongly sericitized and kaolinized feldspars both in phenocrysts and groundmass. The amphibole is pleochroic in deep browns and has resorbed edges; the clinopyroxene is very pale green and has sharp subhedral grain boundaries. This rock, one of the very few that has been dated, has an age between 10 and 20 m.y., which is considered a minimum age.

A dating sample collected from the north edge of the Sutwik Island quadrangle is a hornblende hypa-andesite that is virtually a perfect match for the late Tertiary rocks. The amphibole is in good condition and has yielded an age of $19.4 \pm 0.16$ m.y. The feldspar is nearly completely altered to sericite; what remains is strongly zoned with Carlsbad and minor albite twinning.

\section{SUMMARY}

The geochronologic work undertaken here has indicated two important Tertiary magmatic episodes in the Chignik-Sutwik Island area. These episodes may correspond to similar events in the Aleutian Island (DeLong and others, 1978) though here they occur about 5 to 10 m.y. later. This lapse may be related to the propagation rate along the Aleutian Trench. One episode, occurring about 34 m.y., represents the Tolstoi-Meshik arc. The large volume and wide distribution of volcaniclastic rocks of the Tolstoi Formation and volcanic rocks of the Meshik Formation tend to confirm the importance of this event.

\section{MEGAFOSSIL DATA MAP (MF-1053-N)}

A considerable amount of new data on the fossil megafauna and flora was obtained during the present investigations. About 200 collections, many of them from areas that had never been collected, added considerably to the data base for this part of Alaska and helped greatly in the interpretation of the stratigraphy. Fossils were collected from rocks ranging in age from Middle Jurassic (Callovian) to late Miocene (Wishkahan).

The localities shown on the map and the fossils listed in the tables were all collected during 1977 and 1978. Previous Mesozoic (post-Callovian) collections in the area are listed in Jones and Miller (1976). The Middle Jurassic (Callovian) fossils are of particular interest as they extend the known area of exposed Shelikof Formation (Jurassic) $150 \mathrm{~km}$ to the southwest down the 
Alaska Peninsula. The many excellent collections of Tertiary plants will add greatly to our knowledge of the flora of this area and include many new undescribed genera and species.

The large collections of late Tertiary mollusks were identified by $L$. N. Marincovich of the Geological Survey and the echinoids by C. W. Allison of the University of Alaska, Fairbanks,
Alaska. The numerous specimens of early and middle Tertiary megaflora were identified by J. A. Wolfe of the Geological Survey, and the Late Cretaceous specimens by R. A. Spicer, Imperial College, London, England. J. W. Miller and D. L. Jones of the Geological Survey identified the Cretaceous megafauna and the Jurassic pelecypods. The Jurassic ammonites were identified by R. W. Imlay. 


\section{REFERENCES}

\section{Starred references indicate those cited in this report}

Part 1. Specific References (Principally restricted to the Chignik and Sutwik Island quadrangles or references in which the quadrangles constitute a significant part of the report.)

*Atwood, W. W., 1911, Geology and mineral resources of parts of the Alaska Peninsula: U.S. Geological Survey Bulletin $467,137 \mathrm{p}$.

Berryhill, R. V., 1963, Reconnaissance of beach sands, Bristol Bay, Alaska: U.S. Bureau of Mines Report of Investigations 6214, $48 \mathrm{p}$.

*Burk, C. A., 1965, Geology of the Alaska Peninsula--Island arc and continental margin (Part 1): Geological Society of America Memoir 99, $250 \mathrm{p}$.

${ }^{*}$ Case, J. E., Cox, D. P., Detra, D. E., Detterman, R. L., and Wilson, F. H., 1981, Maps showing aeromagnetic survey and interpretation of the Chignik and Sutwik Island quadrangles, Alaska: U.S. Geological Survey Miscellaneous Field Studies Map MF-1053-B, scale 1:250,000, 2 sheets (in press).

*Case, J. E., Barnes, D. F., Detterman, R. L., Morin, Robert, and Sikora, Robert, 1981, Gravity anomaly and interpretation map of the Chignik and Sutwik Island quadrangles, Alaska: U.S. Geological Survey Miscellaneous Field Studies Map MF-1053-J, scale 1:250,000 (in press).

Cobb, E. H., 1972, Metallic mineral resources map of the Chignik quadrangle, Alaska: U.S. Geological Survey Miscellaneous Field Studies Map MF-374, scale 1:250,000.

*Conwell, C. N., and Triplehorn, D. M., 1978, Herendeen Bay-Chignik coals, southern Alaska Peninsula: State of Alaska Department of Natural Recources, Special Report 8, p. 15.

*Cox, D. P., Detra, D. E., and Detterman, R. L., 1981, Mineral resource maps of the Chignik and Sutwik Island quadrangles, Alaska: U.S. Geological Survey Miscellaneous Field Studies Map MF-1053-K, 2 sheets, scale 1:250,000.

*Dall, W. H., 1896, Report of coal and lignite of Alaska: U.S. Geological Survey Annual Report. 17th, 1, p. 763-908.

*Dall, W. H., and Harris, G. D., 1892, Correlation papers: Neocene: U.S. Geological Survey Bulletin 84, 349 p.

*Detra, D. E., and Cooley, E. F., 1980a, Distribution and abundance of copper in minus-80-mesh stream-sediment and nonmagnetic heavy-mineral- concentrate samples, Chignik and Sutwik Island quadrangles, Alaska: U.S. Geological Survey Miscellaneous Field Studies Map MF. 1053-C, 2 sheets, scale 1:250,000.

* _ 1980b, Distribution and abundance of silver and arsenic in nonmagnetic heavy-mineral-concentrate samples, Chignik and Sutwik Island quadrangles, Alaska: U.S. Geological Survey Miscellaneous Field Studies Map MF1053-G, 2 sheets, scale 1:250,000.

Detra, D. E., Cooley, E. F., Day, G. E., O'Leary, R. M., Holloway, C. D., and Yount, M. E., 1978, Results and statistical summary from analysis of stream sediment and heavy-mineral-concentrate samples, Chignik and Sutwik Island quadrangles, Alaska: U.S. Geological Survey Open-File Report 78-345, 96 p.

*Detra, D. E., Cooley, E. F., Hopkins, R. T., Jr., O'Leary, R. M., and Jefferis, D. R., 1978, Final results and statistical summary from analysis of stream-sediment and heavy- mineral-concentrate samples, Chignik and Sutwik Island quadrangles, Alaska: U.S. Geological Survey Open-File Report 78-1090, 105 p.

*Detra, D. E., and Cooley, E. F., 1980c, Distribution and abundance of bismuth, tin, and tungsten in nonmagnetic heavy-mineral-concentrate samples, Chignik and Sutwik Island quadrangles, Alaska: U.S. Geological Survey Miscellaneous Field Studies Map MF-1053-H, scale $1: 250,000$.

*Detra, D. E., and Day, G. W., 1980, Distribution and abundance of molybdenum in minus-80-mesh stream. sediment and nonmagnetic heavy- mineral-concentrate samples, Chignik and Sutwik Island quadrangles, Alaska: U.S. Geological Survey Miscellaneous Field Studies Map MF-1053-F, 2 sheets, scale 1:250,000.

*Detra, D. E., and Hopkins, R. T., Jr., 1980, Distribution and abundance of lead in minus-80-mesh stream-sediment and nonmagnetic heavy-mineral- concentrate samples, Chignik and Sutwik Island quadrangles, Alaska: U.S. Geological Survey Miscellaneous Field Studies Map MF1053-D, 2 sheets, scale 1:250,000.

*Detra, D. E., and O'Leary, R. M., 1980, Distribution and abundance of zinc in minus-80-mesh stream-sediment and nonmagnetic-heavy-mineral concentrate samples, Chignik and Sutwik Island quadrangles, Alaska: U.S. Geological Survey Miscellaneous Field Studies Map MF. 1053-E, 2 sheets, scale 1:250,000.

*Detterman, R. L., 1978, Interpretation of depositional environments in the Chignik Formation, Alaska Peninsula, in Jonson, K. M., ed., The United States Geological Survey in Alaska: Accomplishments during 1977: U.S. Geological Survey Circular 772-B, p. B62-B63.

*Detterman, R. L., Case, J. E., Miller, T. P., and Yount, M. E., 1981, Energy resource maps of the Chignik and Sutwik Island quadrangles, Alaska: U.S. Geological Survey Miscellaneous Field Studies Map MF-1053-L, 3 sheets, scale $1: 250,000$ (in press).

*Detterman, R. L., Miller, T. P., Yount, M. E., and Wilson, F. H., 1979, Generalized geologic map of the Chignik and Sutwik Island quadrangles, Alaska: U.S. Geological Survey Miscellaneous Field Studies Map MF-1053-A, scale $1: 250,000$.

1981, Geologic map of the Chignik and Sutwik Island quadrangles, Alaska: U.S. Geological Survey Miscellaneous Geologic Investigations Map I-1229, scale 1:250,000 (in press).

1981, Quaternary geologic map of the Chignik and Sutwik Island quadrangles, Alaska: U.S. Geological Survey Miscellaneous Geologic Investigations Map I-1292, scale $1: 250,000$ (in press).

*Detterman, R. L., Yount, M. E., and Case, J. E., 1981, Megafossil sample locality map, checklists, and stratigraphic sections for the Chignik and Sutwik Island quadrangles, Alaska: U.S. Geological Survey Miscellaneous Field Studies Map MF-1053-N, 2 sheets, scale 1:250,000 (in press).

Fairchild, D. K. T., 1977, Paleoenvironments of the Chignik Formation, Alaska Peninsula: College, University of Alaska, M.S. thesis, 168 p.

Jones, D. L., 1963, Upper Cretaceous (Campanian and Maestrichtian) ammonites from southern Alaska: U.S. Geological Survey Professional Paper 432, 53 p.

*Jones, D. L., and Miller, J. W., 1976, Preliminary geologic map of the Alaska Peninsula showing post-Callovian Mesozoic fossil localities: U.S. Geological Survey OpenFile Report 76-76, 2 sheets, scale 1:500,000. 
*Keller, A. S., and Cass, J. T., 1956, Petroliferous sand of the Chignik Formation at Chignik Lagoon, Alaska: U.S. Geological Survey Open-File Report 56-71, 5 p.

*Kienle, Juergen, and Turner, D. L., 1976, The ShumaginKodiak batholith-- A Paleocene magmatic arc?: State of Alaska Department of Natural Resources, Geology Report 51, p. 9-11.

*Knappen, R. S., 1929, Geology and mineral resources of the Aniakchak district: U.S. Geological Survey Bulletin 797, p. 161-227.

Le Compte, J. R., and Steele, W. C., 1981, Maps showing interpretation of Landsat imagery of the Chignik and Sutwik Island quadrangles, Alaska: U.S. Geological Survey Miscellaneous Field Studies Map MF-1053-0, 2 sheets, scale 1:250,000.

Lyle, W. M., and Dobey, P. I., 1973, Geology and mineral evaluation of the Aniakchak drainage, Alaska Peninsula: Alaska Division of Geological and Geophysical Surveys Open-File Report AOF-26, 18 p.

Martin, G. C., 1925, The outlook for petroleum near Chignik: U.S. Geological Survey Bulletin 773, p. 209-213.

* 1926, The Mesozoic stratigraphy of Alaska: U.S. Geological Survey Bulletin 776, 493 p.

McLean, Hugh, 1977, Organic geochemistry, lithology, and paleontology of Tertiary and Mesozoic rocks from wells on the Alaska Peninsula: U.S. Geological Survey Open-File Report 77-813,68 p.

Miller, T. P., and Smith, R. L., 1977, Spectacular mobility of ash flows around Aniakchak and Fisher calderas, Alaska: Geology, v. 5, p. 173-176.

Pickthorne, W. J., Yount, M. E., Cooley, E. F., O'Leary, R. M., Detra, D. E., and Ito, Gail, 1979, Sample location map and analytical data for rock samples collected in 1978, Chignik and Sutwik Island quadrangles, Alaska: U.S. Geological Survey Open-File Report 79-1506, scale $1: 250,000$.

*Smith, W. R., 1924, Aniakchak Crater, Alaska Peninsula: U.S. Geological Survey Professional Paper 132-J, p. J139-J145.

*Smith, W. R., and Baker, A. A., 1924, The Cold Bay-Chignik district, Alaska: U.S. Geological Survey Bulletin 755, p. 151-218.

*Tripp, R. B., and Detra, D. E., 1980, Maps showing mineralogical data of selected minerals for the nonmagnetic heavy-mineral concentrates of stream sediments in the Chignik and Sutwik Island quadrangles, Alaska: U.S. Geological Survey Miscellaneous Field Studies Map MF-1053-I, 2 sheets, scale 1:250,000.

United States Geological Survey, 1978a, Aeromagnetic map of Chignik and Sutwik Island quadrangles, Alaska: U.S. Geological Survey Open-File Report 78-262, scale $1: 250,000$.

$1978 \mathrm{~b}$, Aeromagnetic maps of the Chignik and Sutwik Island quadrangles, Alaska: U.S. Geological Survey OpenFile Report 78-263, 11 sheets, scale 1:63,360.

*Waring, G. A., 1917, Mineral springs of Alaska, with a chapter on the chemical character of some surface waters of Alaska, by R. B. Dole and A. A. Chambers: U.S. Geological Survey Water-Supply Paper 418, 118 p.

Wilson, F. H., 1978, Map showing preliminary results of K-Ar studies in the Chignik and Sutwik Island quadrangles, Alaska: U.S. Geological Survey Open-File Report 781064.

1980, Late Mesozoic and Cenozoic tectonics and the age of porphyry copper prospects; Chignik and Sutwik Island quadrangles, Alaska, Hanover, Dartmouth College, Ph.D. thesis, $178 \mathrm{p}$.

Wilson, F. H., Detterman, R. L., and Silberman, M. L., 1978, New ages on intrusive rocks and altered zones on the Alaska Peninsula, in Johnson, K. M., ed., The United States Geological Survey in Alaska: Accomplishments during 1977: U.S. Geological Survey Circular 772-B, p. B63-B65.

Wilson, F. H., Gaum, W. C., and Herzon, P. L., 1981, Map and tables showing geochronology and whole rock chemistry, Chignik and Sutwik Island quadrangles, Alaska: U.S. Geological Survey Miscellaneous Field Studies Map MF-1053-M, scale 1:250,000 (in press).

Yount, M. E., Cooley, E. F., and O'Leary, R. M., 1978, Sample location map, analytical data, and statistical summary of analyses of rock samples, Chignik and Sutwik Island quadrangles, Alaska: U.S. Geological Survey Open-File Report 78-557, scale 1:250,000.

Part 2. General References (Principally references of regional scope in which the Chignik and Sutwik Island quadrangles are incidental to the main theme of the paper.)

Alaska Division of Geological and Geophysical Surveys, 1974, Annual Report 1973: Anchorage, Alaska, 59 p.

Alaska Division of Geological Survey, 1970, Report for the year 1970: College, Alaska, 86 p. 1972, Annual report 1971: Anchorage, Alaska, 109 p.

Alaska Division of Mines and Minerals, 1965, Report for the year 1965: Juneau, Alaska, 99 p.

Alaskan Geology Branch, U.S. Geological Survey, 1972, The status of mineral resource information on the major land withdrawals of the Alaska Native Claims Settlement Act of 1971: U.S. Geological Survey Open-File Report 72-394, $164 \mathrm{p}$.

Armstrong, R. L., Harakal, J. E., and Hollister, V. F., 1976, Age determinations of late Cenozoic porphyry copper deposits of the American Cordillera: Institute of Mining and Metallurgy Transactions, Section B, v. 85, p. 239-244.

Atwood, W. W., 1909, Mineral resources of southwestern Alaska: U.S. Geological Survey Bulletin 379-C, p. 108-152.

*Barnes, D. F., 1967, Four preliminary gravity maps of parts of Alaska: U.S. Geological Survey Open-File Report $67-10,5 \mathrm{p}$.

*__ 1977, Bouguer gravity map of Alaska: U.S. Geological Survey Geophysical Investigations Map GP-913, scale $1: 2,500,000$.

Barnes, F. F., 1967, Coal resources of Alaska: U.S. Geological Survey Bulletin 1242-B, p. B1-B36.

Becker, G. F., 1898, Reconnaissance of the gold fields of southern Alaska, with some notes on general geology: U.S. Geological Survey 18th Annual Report, Part 3, p. 1-86.

${ }^{*}$ Beckinsale, R. D., and Gale, N. N., 1969, A reappraisal of the decay constants and branching ratio of ${ }^{14} \mathrm{~K}$ : Earth and Planetary Science Letters, v. 6, p. 239-294.

Beikman, H. M., 1975, Preliminary geologic map of the Alaska Peninsula and Aleutian Islands: U.S. Geological Survey Miscellaneous Field Studies Map MF-674, 2 sheets, scale 1:1,000,000.

Berg, H. C., and Cobb, E. H., 1967, Metalliferous lode de- 
posits of Alaska: U.S. Geological Survey Bulletin 1246 , 254 p.

Brockway, Ron, Chairman, Bristol Bay Stratigraphic Committee, 1975, Bristol Bay region, stratigraphic correlation section, soutbwest Alaska: The Alaska Geologic Society.

Brooks, A. H., 1902, The coal resources of Alaska: U.S. Geological Survey Annual Report. 22d, 3, p. 515-571.

1906, The geography and geology of Alaska, a summary of existing knowledge, with a section on Climate by Cleveland Abbe, Jr., and A topographic map and description thereof, by R. U. Goode: U.S. Geological Survey Profegsional Paper 45, $327 \mathrm{p}$.

1908, The mining industry in 1907: U.S. Geological Survey Bulletin 345, p. 30-53.

1909 , Mineral resources of Alaska, in U.S. Geological Survey, Papers on the conservation of mineral resources (reprinted from report of the National Conservation Commission, February, 1909): U.S. Geological Survey Bulletin 394, p. 172-207.

1910 , Alaska coal and its utilization: U.S. Geological Survey Bulletin 442, p. 47-100.

1912, The mining industry in 1911: U.S. Geological Survey Bulletin 520 , p. 17-44.

1921, The future of Alaska mining: U.S. Geological Survey Bulletin 714, p. 5-57.

1923, The Alaskan mining industry in 1921: U.S. Geological Survey Bulletin 739, p. 1-44.

*Bruns, T. R., and von Huene, Roland, 1977, Sedimentary basins of the Bhumagin shelf, western Gulf of Alaska: Houston, Offshore Technology Conference, 9th, p. 41-45.

Capps, S. R., 1934, Notes on the geology of the Alaska Peninsula and Aleutian Islands: U.S. Geological Survey Bulletin 857-D, p. 141-153.

Coats, R. R., 1950, Volcanic activity in the Aleutian arc: U.S. Geological Survey Bulletin, 974-B, p. 35-49.

Cobb, E.H., Wanek, A. A., Grantz, Arthur, and Carter, Claire, 1968: Summary report on the geology and mineral resources of the Bering Sea, Bogoslof, Simeonof, Semidi, Tuxedni, St. Lazaria, Hazy Islands, and Forrester Island National Wildlife Refuges, Alaska: U.S. Geological Survey Bulletin 1260-K, p. K1-K28.

Cobb, E. H., 1973, Placer deposits of Alaska: U.S. Geological Survey Bulletin 1374, 213 p.

*Dalrymple, G. B., and Lanphere, M. A., 1969, Potassiumargon dating-Principles, techniques and applications to geochronology: San Francisco, W. H. Freeman, 258 p.

*DeLong, S. E., Fox, P. J., and McDowell, F. W., 1978, Subduction of the Kula Ridge at the Aleutian Trench: Geological Society of America Bulletin, v. 89, p. 83-95.

Demenistskaya, R. M., and Belyaevsky, N. A., 1969, The relation between the Earth's crust, surface relief, and gravity field in the U.S.S.R., in Hart, P. J., ed., The Earth's crust and upper mantle: American Geophysical Union Monograph 13, p. 312-319.

Dickinson, W. R., 1974, Sedimentation within and beside ancient and modern magmatic arcs, in Dott, R. G., Jr., and Shaver, R. H., eds., Modern and ancient geosynclinal sedimentation: Society of Economic Paleontologists and Mineralogists Special Publication 19, p. 230-239.

*Dow, W. G., 1977, Kerogen studies and geologic interpretations: Geochemical Exploration, v. 7, p. 79-99.

*Engels, J. C., and Ingamells, C. O., 1970, Effect of sample inhomogeneity in K-Ar dating: Geochimica et Cosmochimica Acta, v. 34, p. 1007-1017.

*Garner, E. L., Murphy, T. J., Gramlich, J. W., Paulson, P. J., and Barnes, I. L., 1975, Absolute isotopic abundance ratios and the atomic weight of a reference sample of potassium: Journal of Research, National Bureau of Standards - A. Physics and Chemistry, v. 79A, p. 713-725.

*Gasching, J. C., 1980, Development of uranium exploration models for the Prospector Consultant System: Final Report, Stanford Research Institute, Project 7857, SRI International, Menlo Park, Ca.

Grewingk, Constantin, 1850, Beitrag zur Kenntniøs der orographischen und geognostischen Beschaffenheit der Nordwest Küste Amerikas mit den anliegen Inseln: Verh. andlungen der Russisch-Kaiserlichen Min. Geseel, zu St. Petersburg, 1848-1849, p. 76-424.

*Grimes, D. J., and Marranzino, A. P., 1968, Direct-current arc and alternating-current spark emission spectrographic field methods for the gemiquantitative analysis of geologic materials: U.S. Geological Survey Circular 591 , 6 p.

Hollick, Arthur, 1930, The Upper Cretaceous floras of Alaska, with a description of the plant-bearing beds, by G. C. Martin: U.S. Geological Survey Professional Paper 159,123 p.

1936. The Tertiary floras of Alaska, with a chapter on The geology of the Tertiary deposits, by P. S. Smith: U.S. Geological Survey Professional Paper 182, $185 \mathrm{p}$.

Holloway, C. D., 1977, Map showing coal fields and distribution of coal- bearing rocks in the western part of southern Alaska: U.S. Geological Burvey Open-File Report 77-169-I, scale 1:1,000,000.

Imlay, R. W., 1975, Stratigraphic distribution and zonation of Jurassic (Callovian) ammonites in southern Alaska: U.S. Geological Survey Professional Paper 836, 28 p.

Imlay, R. W., and Detterman, R. L., 1973, Jurassic paleobiogeography of Alaska: U.S. Geological Survey Professional Paper 801, 34 p.

Knowlton, F. H., 1898, A catalogue of the Cretaceous and Tertiary plants of North America: U.S. Geological Survey Bulletin 152, 247 p.

MacKevett, E. M., Jr., and Holloway, C. D., 1977, Map showing metalliferous mineral deposits in the western part of southern Alaska: U.S. Geological Survey Open-File Report 77-169-F, scale 1:1,000,000.

1977, Table describing metalliferous mineral deposits in the western part of southern Alaska: U.S. Geological Survey Open-File Report 77-169-F, 39 p.

Mancini, E. A., Deeter, T. M., and Wingate, F. H., 1978, Upper Cretaceous arc-trench gap sedimentation on the Alaska Peninsula: Geology, v. 6, p. 437-439.

Marlow, M. S., Alpha, T. R., Bcholl, D. W., and Buffington, E. C., 1975, Bering Sea shelf, Alaska: U.S. Geological Survey Open-File Report 75-1, 2 sheets.

Martin, G. C., 1907, The Alaska coal fields: U.S. Geological Survey Bulletin 314, p. 40-46. 1921, Preliminary report on petroleum in Alaska: U.S. Geological Survey Bulletin 719, 83 p.

McGee, D. L., 1972, Gulf of Alaska petroleum seeps: Alaska Division of Geological and Geophysical Surveys Open-File Report AOF $\cdot 32,7$ p.

Miller, D. J., Payne, T. G., and Gryc, George, 1959, Geology of possible petroleum provinces in Alaska, with an Anno. tated bibliography by E. H. Cobb: U.S. Geological Survey Bulletin 1094, $131 \mathrm{p}$.

Miller, T. P., 1973, Distribution and chemical analyses of thermal springs in Alaska: U.S. Geological Survey OpenFile Report 73-187, scale 1:2,500,000.

Moore, J. C., 1973, Cretaceous continental margin sedimen- 
tation, southwestern Alaska: Geological Society of America Bulletin, v. 84, p. 595-614.

Moxham, R. M., 1951, Pumice deposits in the Alaska Peninsula-Cook Inlet region, Alaska: U.S. Geological Survey Open-File Report 52-103, 21 p.

*Packer, D.R., and Stone, D. B., 1974, Paleomagnetism of Jurassic rocks from southwestern Alaska and their implication: Canadian Journal of Earth Sciences, v. 11, p. 976-997.

*Racklay, R. I., 1976, Origin of western states-type uranium mineralization, in Wolf, K. H., ed., Handbook of stratabound and strataform deposits: Amsterdam, Elsevier, p. 89-152.

Smith, P. S., 1939, Areal geology of Alaska: U.S. Geological Survey Professional Paper 192, 100 p.

*Smith, R. L., and Shaw, H. R., 1975, Igneous-related geothermal systems, in White, D. E., and Williams, D. L., eds., Assesment of geothermal resources of the United States-1975: U.S. Geological Survey Circular 726, p. 58-83.

*Stone, D. B., and Packer, D. R., 1979, Paleomagnetic data from the Alaska Peninsula: Geological Society of America Bulletin, Part 1, v. 90 , p. 545-560.

Stone, R. W., 1905, Coal resources of southwestern Alaska: U.S. Geological Survey Bulletin 259, p. 151-171.

*Streckeisen, Albert, 1976, To each plutonic rock its proper name: Earth-Science Reviews, v. 12, p. 1-33.

1979, Classification and nomenclature of volcanic rocks, lamprophyres, carbonatites, and melilitic rock: Recommendations and suggestions of the IUGS Subcomission on the Systematics of Igneous Rocks: Geology, v. 7, p. 331-335.

U.S. Bureau of Mines, 1946, Analyses of Alaska coals, with a section on Coal fields of Alaska, by G. O. Gates: U.S. Bureau of Mines Technical Paper 682, 114 p.
U.S. Geological Survey, 1899, Maps and descriptions of routes of exploration in Alaska in 1898, with general information concerning the Territory: U.S. Geological Survey Special Publication, $138 \mathrm{p}$.

Von Huene, Roland, Smith, Rodney, Hampton, Monty, Moore, George, and Dolton, Gordon, 1975, A preliminary summary of petroleum potential, environmental geology, and the technology, time-frame, and infrastructure for exploration and development of the western Gulf of Alaska: U. S. Geological Survey Open-File Report 75-536, $54 \mathrm{p}$.

Warfield, R. S., 1967, Resume of information on Alaskan bituminous coals with particular emphasis on coking characteristics: U.S. Bureau of Mines Open-File Report 11-67, $20 \mathrm{p}$.

*Ward, F. N., Nakagawa, H. M., Harms, T. F., and Van Sickle, G. H., 1969, Atomic-absorption methods of analysis useful in geochemical exploration: U.S. Geological Survey Bulletin $1289,45 \mathrm{p}$.

Wedow, Helmuth, Jr., White, M. G., and Moxham, R. M., 1952 , Interim report on an appraisal of the uranium possibilities of Alaska: U.S. Geological Survey Open-File Report 52-165, $123 \mathrm{p}$.

Wolfe, J. A., 1972, An interpretation of Alaskan Tertiary floras, in Graham, A., ed., Floristics and paleofloristics of Asia and eastern North America: Amsterdam, Elsevier, p. 201-233.

Wolfe, J. A., Hopkins, D. M., and Leopold, E. B., 1966, Tertiary stratigraphy and paleobotany of the Cook Inlet region, Alaska: U.S. Geological Survey Professional Paper 398-A, p. A1-A29.

Wollard, G. P., and Strange, W. E., 1962, Gravity anomalies and crust of the Earth in the Pacific Basin, in MacDonald, G. A., and Kuno, Hisashi, eds., The crust of the Pacific Basin: American Geophysical Union Geophysical Monograph 6, p. 60-80. 